\title{
ROLE OF FACILITIES AVAILABLE AND UN-AVAILABLE IN ATTRACTING OF TOURIST IN SWAT VALLEY PAKISTAN
}

\author{
JALALUDDIN AKBAR $^{{ }^{*}}$, SYED TANVEER SHAH ${ }^{2}$, \\ MUHAMMAD NAEEM KHAN ${ }^{3}$, AHMAD NAEEM $^{4}$ \\ ${ }^{1}$ Horticultural Manger at Horti group Lahore Pakistan (Jalaluddin Akbar) \\ ${ }^{2}$ Lecturer at the University of Agriculture Peshawar Pakistan (Syed Tanveer shah) \\ ${ }^{3}$ Mphil Scholar at University of Agriculture Peshawar Pakistan (M Naeem Khan) \\ ${ }^{4}$ Horticultural Manger at SKTH hospital Peshawar (Ahmad Naeem) \\ *Corresponding author, e-mail: Jalalakbar@aup.edu.pk
}

Received: $30^{\text {th }}$ July 2016, Accepted: $6^{\text {th }}$ November 2016

\begin{abstract}
Natural landscape is an important resource for mountainous regions and play crucial role in tourism development. Tourism play a key role in economic development of a country. Developing tourist areas is the key to meet the expectations of mountain inhabitants, tourists, and the general public outside of mountainous areas. In order to know tourist perception, problems, and role of landscape \& horticulture plants in the field of tourism. A research study entitled "Role of facilities available and un-available in attracting of tourist in swat valley Pakistan "The data was collected from the respondents through a questionnaire survey and analyzed using percentages, frequencies and Chi-square test (where applicable). The analyzed data revealed that most of the respondent $(55 \%)$ considered natural green environment as a reason for their visit and $67 \%$ respondents wanted to visit with their friends and were satisfied with the tourist area, respectively. Most of the respondent (39\%) observed throwing of surplus food as major waste materials which turned the beautiful green environment into unattractive environment. Most of the visitors (52\%) dislike un-cleanliness of the locality, $74 \%$ respondents felt ill effect due to deforestation.53\% tourist disagree with the current maintenance of the locality by tourism department. The most missed facilities were non availability of dustbins and children playing areas. $75 \%$ respondents agreed with the fact that most of the people (local inhabitants as well as tourist) were unaware with regard to maintenance activities of the area $15.7 \%$ respondent agreed that road system should be improved to access most of the greenery in the locality, respectively to aware local people and tourist regarding maintenance of the locality will improve tourism in Swat valley. The studies need to be develop for the improvement of existing as well as artificial landscape of the tourist area (Kalam and Malamjabba) of Swat valley.
\end{abstract}

Keywords: Tourist area, facilities, waste material, perception, satisfaction, accompanying

\section{INTRODUCTION}

Tourism mean travelling of peoples to destinations away from their usual living places and the provision of facilities created to fulfill the needs arising along this travel (Mathieson \& 
Akbar J., Shah S.T, Khan M.N, Naeem A.: Role of facilities available and un-available in attracting of tourist in swat valley Pakistan

Wall, 1982). A latest definition broaden the scope of tourism, defining it as the set of activities performed by people who travel and stay in places outside their usual environment for not more than consecutive year, for leisure, business and other purposes (The European Commission, 2002). Tourism expect a significant part for a few countries in making social and monetary change and decreasing of destitution, through the obtainment of occupations and endeavors, establishment headway and charge salary. All around organized and supervised tourism can not simply make a basic responsibility of sensible progression, moreover make not all that decent occupations and produce trade opportunities (Gutierrez, 2012). However In any case, tourism can't act normally self-supporting since it depends upon the availability of natural ecosystem (Ahmad, 2012).

Tourism has four main principle parts "settlement" the fundamental segments of tourism. "Availability" implies by which a traveler can achieve the region where regular habitat are located."Amenities" implies the fundamental facilities provided in visitor resorts. Fascination implies a position of interest where voyagers are pulled in to visit, regularly for its intrinsic or displayed social worth, chronicled importance, characteristic or manufactured magnificence, or delight opportunities (Arjun, 2013).

Kaplan (1992) has carried out relevant studies to understand the reactions of people and the need for natural environments. Even wilderness areas have been affected by our forests and roads and physical facilities provided entertainment offered. Researchers on the role of nature or nature to influence people often refer to vegetation trees and park area, which is the fields and forests or cultivated atrium.

Swat valley situated in the Northwest part of Khyber Pakhtunkhwa, which is the most fascinating, precipitous and greener with streams, waterfalls and rivers. Its primary attractions incorporate valleys of Maindam, Bahrain, Malamjabba and Kalam. In this way, this locale is prevalent with trackers, mountain climbers and explorers and also skiing in winter at popular Ski resort of Malam Jabba (Pakistan tourism and travel guide, 2006).

Militancy and contradict militancy influenced the valley in each circle of life yet maybe the most noticeably bad harm done, among numerous, was to its tourism. As per an evaluation, the tourism business was influenced with lost more than 8 billion rupees in the most recent three years. Amid these barbarous years, sundry vacationer resorts to be specific Kalam, Bahrain, Miyadam, Madyan, Fiza Gat, MalamJabba and Murghzar were forsaken, miserable and singular. Nonetheless, after prosperous operation of Pakistan armed force, while destroying extremist, the valley has picked up its shape favoring tourism, which languished with 75 billion misfortunes over 2007 ahead with a prominent bit of Rs. 7.5 billion from inn industry (Khan, 2010).

Visitor perception and issues in relation to to facilities are noticeably composite. Even though a lot of emphasis has been put on facilities available in the tourist area from different perspective and on preferences of natural green environment in contrast to regular living places.Studies focusing on identification of people perception and problems. This has encouraged the current research study to test the theories about tourist perception, issues and problems to overcome tourist low frequency.

\section{Objectives of research study:}

To identify problem faced by visitor at the tourist area.

$>$ To suggest the role of facilities available and facilities not available in increasing tourist frequency 
$>$ The literature work on the role of natural landscape toward improvement in tourism industry is reviewed as under

$>$ Kastenholz et al. (2012) studied marketing the rural tourism experiencein Portugal's Central Region. They verified that past encounters of visitors in characteristic green environment in traveler resorts and the current supply of resources and facilities must be taken as key-components and considered in an incorporated point of view for giving impressive experiences.

$>$ Arnberger \& Eder (2011) in his study Coping as a Moderator of The Relation between Recreation Hassles and Hiker Satisfaction, includingsurveys were conducted on trails in Yangmingshan National Park in Taiwan. The study's outcomes demonstrated that the tourist perceptions of natural landscape emerge as a consequential implement for tourist destinations to identify the elements of the natural environment most esteemed by tourists and to change the experience offered to the visitors in recreational resorts. Number of studies have been led to decide tourists discernments about natural landscape and comprehend the effective significant of greenery involvement with recreational zones.

$>$ Aranzabal et al. (2009) Integrating Landscape Analysis and Planning: A Multi-Scale Approach for Oriented Management of Tourist Recreation research was conducted in Linhares da Beira, Portugal. The exploratory findings uncovered that Environmental Management suggested that ecological quality are tourists territory assets that have turned out to be a piece of the tourism experience looked for by additionally requesting visitors and that to considered, characterized one of the principle goals of the destination administration to give quality memorable experience based upon natural environment.

> Clivaz (2008) studied living Terraced Landscapes-Perspectives and Strategies to Revitalized Abandoned Regions Ljubljana Slovenia. Research findings revealed that few parts of natural landscape in traveler destinations incorporates the change of natural quality by giving the view of the fascination, upgrades environment through the general beautification of the earth, enhances Infrastructure frameworks. Which gives financial benefits and ecological advantages, Preservation of fundamental environment by protecting nature and other recreational environment.

> Fredman \& Lindberg (2008) paper present special focus: Mountain tourism Introduction. Tourism Economics conducted in Sweden. Confirm that natural landscapes and wildlife as well as their cultural attractions inhilly areasexiston earth are the fundamental destinations for amusement and tourism

$>$ Jensen \& Koch (2004) performed Forest Recreation Research in Denmark and its influence on Forest Policy in Scandinavia During his research they performed a series of recreation surveys which over the possibility to associatenatural environment recreation involvement over time Danish surveys revealed visiting to forests and natural green environment include a remarkable set of data about forest and natural landscape preferences.

> Buckley (2003) studied The Practice and Politics of Tourism and Land Management", in Nature-based Tourism, Environment and Land Management in Cambridge, study finding expressed that tourism predicated on regular habitats is an increasing universal industry with major monetary, festive and ecological results at both nearby and worldwide scales. 


\section{MATETIALS AND METHODS}

\section{Introduction to the topic}

Tourists from Swat valley (Kalam and Malamjabba) were interviewed to identify the perceptions, issues and concerns of tourist area in relation to improvement of tourism industry in Swat valley. The study adopted the quantitative method of data collection combined with the review of literature in order to gauge the views of tourism in Swat valley on the potential role of facilities in tourism development. The quantitative method also allows the gauge of data in numerical terms, using closed ended questionnaires. Data collected from tourist regarding perception, problem facing in the tourist area will help to improve and cover the current condition of the tourist locality. The study is important in order to to identify tourist views about natural landscape, and problems faced by tourist in tourist locality.

\section{Research Questioners}

For the purpose of achieving goal of the study following questions wereincluded in questionnaire.

A. Respondent profile

i. Age

ii. Gender

iii. Education

1. What are the main reasons for visiting tourist area?

2. How much time you have visited the tourist locality i.e. Kalam and Malamjabba?

3. Who is accompanying you for visiting tourist area?

4. Is natural greenery of the tourist area satisfied you?

5. Is the area free from waste materials?

6. If no, which types of waste materials you observed?

7. Which things you most disliked during your visit?

8. Do you feel any impact due to de-forestation?

9. Enlist facilities not available in the locality?

10. What is your suggestion to improve the tourist area (Kalam and Malamjabba) further?

\section{Reason for selecting Swat valley as a case study}

To find out and analyze tourist perceptions, problems and role of horticulture in the field of tourism, the respondents were selected from two different location (Kalam, Malamjabba) in Swat valley. Reason for selecting Malamjabba and Kalam in Swat valley are,

- Areas under study were the top recreational resorts for tourist in Swat valley.

- Both have abundant natural greenery, river and mountains and ground cover.

- Survey site was in the same area (Swat) approximately similar in size to minimized population differences, distances and size on perception and problems.

Therefore, most of the tourist prefers these areas (Kalam and Malamjabba. On the basis of improvement of tourism in Swat valley Kalam and Malamjabba were selected for research study. 


\section{Pilot survey}

Pilot survey was conducted in targeted area prior to undertake main survey. Ten tourists were randomly selected. Pilot survey was conducted

- To check the efficiency of the future survey,

- Helps to determine difficulties before commencing of main survey.

- Also to check whether language used in the questionnaire was understandable or not.

Based on analysis of this pilot survey the questionnaire was redesigned, putting the feedback recovered from the respondents. The revised questionnaire was used in main survey.

\section{Sampling procedures}

Respondents were selected randomly from the tourist spots. The data were collectedfrom Kalam and Malamjabba visitors. Which was held in the month of July, August and September respectively? Some respondents were selected in group while otherswere individually. The nature of the survey was based on comparing variables due to which respondent were asked questions about natural green environment and give free hand to select their own choice.

\section{Sample size}

In order to undertake the survey about "Role of natural landscape in boosting up tourism in swat valley.A sample of 300 respondents were selected from the tourist locality i.e. 150 each from Kalamand Malamjabba based on the visited frequency of the respondents. About 300 questionnaireswere distributed and all questionnaires were collected from the respondents.

\section{Data analysis}

The collected from tourist area (Kalam and Malamjabba) was analyzed using Statistical package for the social sciences SPSS(V. 20) was used to analyze the data collected from touristresorts. Frequencies and percentages were also calculated by using SPSS as a tool, Chi-square test was applied where needed. (Zguner \& Kendle, 2006)

\section{RESULT AND DISCUSSION}

This chapter deals with the analysis, interpretation and discussion of the data collected from the selected respondents in the study area (Swat valley) through pre-tested questionnaire in the tourist resorts.

\section{Respondent profile}

The data in Table 1 indicates percentages of different age groups with regard to their education levels and gender groups. Chi-Square test suggests that there is a cross association between the age groups in relation to gender and education. Most of the respondents $(50.33 \%)$ were adults. $49 \%$ were teenagers and $0.7 \%$ were senior citizens. Regarding education level $35.6 \%$ (25.3\% teenagers, $10.3 \%$ adults \& $0 \%$ senior citizen) were educated up to undergraduate level. While $14.3 \%$ were educated up to secondary level. Gender also has a close association with age groups. $89.7 \%$ respondents were male while $10.3 \%$ were female 
Akbar J., Shah S.T, Khan M.N, Naeem A.: Role of facilities available and un-available in attracting of tourist in swat valley Pakistan

Table 1: Respondents profile in relation to education levels and gender groups

\begin{tabular}{lcccc}
\hline & \multicolumn{4}{c}{ Age groups } \\
\cline { 2 - 5 } Education levels & $\begin{array}{l}\text { Teenager } \\
\mathbf{1 3 - 1 9}(\%)\end{array}$ & $\begin{array}{l}\text { Adult } \\
\mathbf{2 0 - 5 9}(\boldsymbol{\%})\end{array}$ & $\begin{array}{l}\text { Senior } \\
\text { Citizen } \\
\mathbf{6 0}^{+}(\boldsymbol{\%})\end{array}$ & Total(\%) \\
\hline Secondary & $25(8.3)$ & $17(5.7)$ & $1(0.3)$ & $43(14.3)$ \\
Intermediate & $46(15.3)$ & $21(7.0)$ & $1(0.3)$ & $68(22.7)$ \\
Under graduate & $76(25.33)$ & $31(10.3)$ & $0(0.0)$ & $107(35.6)$ \\
Graduate & $0(0.0)$ & $82(27.3)$ & $0(0.0)$ & $82(27.3)$ \\
\hline Total & $\mathbf{1 4 7}(\mathbf{4 9})$ & $\mathbf{1 5 1}(\mathbf{5 0 . 3 3})$ & $\mathbf{2 ( 0 . 7 )}$ & $\mathbf{3 0 0}(\mathbf{1 0 0})$ \\
\hline
\end{tabular}

\begin{tabular}{lccc}
\hline \multicolumn{2}{c}{ Gender } & & \\
\hline Male & $123(41.0)$ & $144(48.0)$ & $2(0.7)$ \\
Female & $24(8.0)$ & $7(2.3)$ & $0(0.0)$ \\
\hline Total & $\mathbf{1 4 7 ( 4 9 . 0 )}$ & $\mathbf{1 5 1}(\mathbf{5 0 . 3 3})$ & $\mathbf{2 ( 0 . 7 )}$ \\
\hline
\end{tabular}

Chi Square: 41.64

Chi-square: 11.219

\author{
P-value : 0.00 \\ P-value: $\quad 0.004$
}

\section{Reasons for visiting tourist areas}

Generally people visit tourist area for several reasons. Respondents were specifically asked to identify the reasons for their visit in relation to gender groups.

Chi-square test shows a significant association between the reason for visiting tourist place and gender groups. The respondents were asked about thereason for their visit to know and improve the tourist areas. It is clear from the Table 2 that most of the respondents $55.3 \%$ (53\% male, $2.3 \%$ female) suggested that the reason for their visit to the tourist place is because of Natural green environment, followed by $21.3 \%$ (19\% male, $2.0 \%$ female) were the opinion that they visited for the reason of outing and relaxation during their visit to the tourist area, while $9.6 \%$ respondents suggested other (Picnic, hiking, photography etc).

The reason for choosing, Natural green environment of the tourist locality by the majority of the respondents is because natural greenery, beauty and scenic views created an enabling environment of achieving relaxation and enhanced physical health. By providing access to natural environment, improves and maintains human health and well being both at an individual and community level Area with high-value natural resources like forest, ground cover, trees, shrubs, mountains, unique flora and fauna, and great scenic beauty attracts tourists, Open greenery is the best place where people can understand the knowledge about the plants and much about the ecology. 
Comparative results were given by hartig (1991) that the nearness of regular landscape can affect on the human personality. Researcher also recommended that other than changes in physical wellbeing, exercise in greenery improve mental health.Studies have found that recreational activities performed in a natural green environment resulted in improvement in self-esteem and mood (Pretty et al., 2007).

Related results were found by Browne (1992) determined that among tourist resorts, area with pleasant andlandscaped grounds were important (48.5\%) or essential $(50.5 \%)$ to $99 \%$ of the residents. The naturallandscape was given as the most important reasons for selecting the particular locality.

Table 2: Reasons for visit in relation to gender groups

\begin{tabular}{lccc}
\hline \multirow{2}{*}{ Reasons for visiting } & \multicolumn{3}{c}{ Gender } \\
\cline { 2 - 4 } & Male (\%) & Female (\%) & Total (\%) \\
\hline Natural green environment & $160(53)$ & $7(2.3)$ & $167(55.7)$ \\
Outing and relaxation & $58(19.3)$ & $6(2.0)$ & $64(21.3)$ \\
Visiting relatives & $12(4.0)$ & $1(0.3)$ & $13(4.3)$ \\
Friends & $16(5.3)$ & $11(3.7)$ & $27(9.0)$ \\
Others & $23(7.66)$ & $6(2)$ & $29(9.6)$ \\
\hline Total & $\mathbf{2 6 9 ( 8 9 . 7 )}$ & $\mathbf{3 1}(\mathbf{1 0 . 3})$ & $\mathbf{3 0 0}(\mathbf{1 0 0})$ \\
\hline
\end{tabular}

Chi-square: $39.88 \quad$ P-value: 0.00

\section{Visitor frequency to the tourist area}

Frequency of the tourist is directly proportional to the maintenance and facilities of the tourist locality. Adequate facilities and well developed maintenance of the locality ensure more frequent visit. Respondents were asked about their visit frequency to find out the number of times they visited the tourist locality.

Chi-square test showed anon significant association between frequencies of respondent in relation to gender groups. However, majority of the respondents $35 \%$ (32.3\% male, $2.7 \%$ female) visited tourist area only once followed by $20 \%$ (13.7\% male and $3.7 \%$ female) visited 3 time with the lowest percentage.

The reason behind lowest percentage of visiting tourist area is because of poor road system, transportation and lack of basic facilities like accommodation, cleanliness program and lack of food shop.

Related results were found by Tribe et al. (2000) stated that sustainable tourism administration can result in maximizing the tourist frequency visit to the tourist resorts. Therefore the tourism department ought to take care in securing natural landscape, minimizing ecological impact, giving fundamental facilities and take caring of natural beautifications. 
Akbar J., Shah S.T, Khan M.N, Naeem A.: Role of facilities available and un-available in attracting of tourist in swat valley Pakistan

Table 3: Tourist visit frequency in relation to gender groups

\begin{tabular}{lccc}
\hline \multirow{2}{*}{ Visiting frequency } & \multicolumn{3}{c}{ Gender } \\
\cline { 2 - 4 } & Male (\%) & Female (\%) & Total (\%) \\
\hline$I^{\text {st }}$ Time & $97(32.3)$ & $8(2.7)$ & $105(35)$ \\
$2^{\text {nd }}$ Time & $59(19.7)$ & $4(1.3)$ & $63(21.0)$ \\
$3^{\text {rd }}$ Time & $50(16.7)$ & $11(3.7)$ & $61(20.3)$ \\
More times & $63(21.0)$ & $8(2.7)$ & $71(23.7)$ \\
\hline Total & $\mathbf{2 6 9 ( 8 9 . 7 )}$ & $\mathbf{3 1}(\mathbf{1 0 . 3})$ & $\mathbf{3 0 0}(\mathbf{1 0 0})$ \\
\hline
\end{tabular}

Chi-square: 5.84

P-value: 0.11

\section{Respondents Accompany for the tourist resorts}

Traveling especially to a tourist area alone is very difficult and when someone is along with making the journey very good, so in similar manner respondents were specifically asked to mention the people who accompanied him to the tourist area or they visited to the tourist place alone.

Table 4 represents the company of the respondents to the tourist places in relation to gender groups. Chi-square test shows the significant association between tourists accompanying in relation to gender groups. Majority of the respondents $67.7 \%$ (65\% male and $2.7 \%$ female) visited to the tourist area along with friends to the tourist resort, followed by $23.66 \%$ visited along with their families and $8.7 \%$ male visited alone.

The reason behind the majority of the respondent's visited with their friend is because of most of the respondents were from different education groups wanted to visit with their universities, colleges and school friends. Less number of female visited tourist areas due to their culture gap.

Vos (2007) noticed that there is a pattern among visitor far from normal living places having groups tour to individual recreational tours, regularly joined by family and companions. Comparative finding were found by Kumar et al. (2009) as per their results tourism likewise offers adventure alongside companions to meet fascinating individuals, make kinships, find out about the world, and open themselves to new points of view.

Table 4: Respondents Accompany in relation to gender groups

\begin{tabular}{lccc}
\hline \multirow{2}{*}{ Accompany } & \multicolumn{3}{c}{ Gender } \\
\cline { 2 - 4 } & Male (\%) & Female (\%) & Total (\%) \\
\hline Friends & $195(65)$ & $8(2.7)$ & $203(67.7)$ \\
Family & $48(16.0)$ & $23(7.6)$ & $71(23.66)$ \\
Alone & $26(8.7)$ & $0(0.0)$ & $26(8.7)$ \\
\hline Total & $\mathbf{2 6 9}(\mathbf{8 9 . 7})$ & $\mathbf{3 1}(\mathbf{1 0 . 3})$ & $\mathbf{3 0 0}(\mathbf{1 0 0})$ \\
\hline
\end{tabular}

Chi-square: 28.95

P-value: 0.00 


\section{Satisfaction level about natural greenery of the tourist area}

Most of the people are attracted by natural landscape. A number of studies shown that natural green environment can improve human physical and mental health which meet their expectation. Respondents were asked about their overall satisfaction from natural green environment in relation to gender groups. Chi-Square test shows significant difference between overall expectations from natural greenery in relation to gender groups. Most of the visitors $76 \%$ (74\% male, $2.3 \%$ female) strongly agree with the opinion that natural green landscape meets their satisfaction. Similarly $16 \%$ selected disagree.

The reason for agreeing with the satisfaction from natural greenery of the tourist resorts is because people generally prefer those area which they have a good time and they can need artificial environment \&busy schedule, so natural greenery is the only and known fact through which people can relax mentally as well as physically. Natural greenery in tourist place plays a vital role in the attraction of people to that place. If the environment of the tourist locality is good so people can visit to those area, where greenery is present. Most of the respondents were satisfied with natural greenery of the tourist place, which strongly confirm that Natural greenery play a vital role the attraction of visitors.

The present result was confirmed by Bigné \& Andreu (2004) defined various elements are required for visitor fulfillment with a specific destination that includes the desires created before and during the outing from the greenery, ground spread, and also the traveler's impression of the administration got.

Chi \& Qu (2008) distinguished seven destinations properties which create visitor fulfillment. It incorporates attractions, occasions and exercises, characteristic scene and access to normal greenery. In one of the studies directed in Southern Italy.

\section{Observation and types of waste Material in tourist area}

Waste materials degrade the beauty of natural green environment which made the attractive greenery to unattractive. Well clean environment free from waste materials ensure more tourist visits. Table 5 shows tourists observed waste materials and types of waste materials. Chi-Square test suggests that there is a significant difference between observed waste materials in relation to types of waste materials.

Majority of respondents $55.7 \%$ of the respondents were strongly agreed with the opinion that ground cover was not free from waste materials while the lowest percentage $4.3 \%$ of the respondents disagreed with the opinion that ground cover are not free from waste material.

The reason behind majority of people agree with the opinion that ground covers were not free from waste material isbecause majority of people visit for picnics. They bring food and other stuff with them. They leave surplus foods over the groundcovers which decreases the beauty of tourist areas. Thereis a trend of utilizing different types of cold drinks and also poly ethane bags in the tourist places. Most of the visitors leave the remaining canes, polyethene bags and other wrapping materials after utilization, which makes the environment un-clean.

Brian (1995) indicated that waste materials considered a standout amongst the most antagonistic ecological effects made by visitors in the tourist resorts. They leave more sum of waste materials, a lot of which become rotted like surplus food waste which make disturbing effect in the locality.

Tribe et al. (2000) demonstrated that in-appropriate waste administration can bring about regular scene degradation and loss of aesthetic value of the tourist locality. 
Akbar J., Shah S.T, Khan M.N, Naeem A.: Role of facilities available and un-available in attracting of tourist in swat valley Pakistan

Table 6: Observation of waste materials in relation to types of waste materials

\begin{tabular}{|c|c|c|c|c|c|}
\hline \multirow[b]{2}{*}{$\begin{array}{l}\text { waste materials } \\
\text { observation }\end{array}$} & \multicolumn{3}{|c|}{ Types of waste } & \multicolumn{2}{|c|}{ materials } \\
\hline & $\begin{array}{c}\text { Throwing } \\
\text { of foods } \\
\text { waste } \%\end{array}$ & $\begin{array}{c}\text { Beverages } \\
\text { cane \% }\end{array}$ & $\begin{array}{c}\text { Poly } \\
\text { Ethane } \\
\text { bags \% }\end{array}$ & $\begin{array}{c}\text { Wrapping } \\
\text { materials \% }\end{array}$ & Total \% \\
\hline Strongly Agree & $79(26.3)$ & $26(8.7 \%)$ & $55(18.3)$ & $7(2.3)$ & $167(55.7)$ \\
\hline Agree & $15(5.0)$ & $16(5.3)$ & $21(7.0)$ & $12(4.0)$ & $64(21.3)$ \\
\hline Undecided & 11(3.6) & $5(1.6)$ & $11(3.6)$ & $2(0.7)$ & $29(9.6)$ \\
\hline Disagree & $9(3.0)$ & $8(2.7)$ & $10(3.3)$ & $0(0.0)$ & $27(9.0)$ \\
\hline $\begin{array}{l}\text { Strongly } \\
\text { Disagree }\end{array}$ & $5(1.7)$ & $4(1.3)$ & $4(1.3)$ & $0(0.0)$ & $13(4.3)$ \\
\hline Total & $119(39.7)$ & 59(19.7) & 101(33.7) & $21(7.0)$ & $300(100)$ \\
\hline
\end{tabular}

\section{Most disliked feature in tourist area}

Respondents were asked about which thing they most dislike during their visit in relation to different age groups. Chi-square test shows significance association between more dislike during their visit in relation to different age groups. Most of the respondents $52 \%$ dislike un cleanliness, $16 \%$ dislike deforestation and $14 \%$ respondent dislike noise.

The reason behind with most of the respondent dislike Un-cleanliness condition of the locality because most of the visitor comes with their families and including children. Children's are unaware of cleanliness, due to unawareness and lake of cleanliness program the throw waste materials directly on groundcovers which makes the tourist area unpleasant. The purpose of their visit has to enjoy natural green and clean environment, if there is lack of cleanliness program defiantly tourist will dislike attractive locality.

Table 7: Respondent choice for the most dislike feature of the tourist locality in relation to different age groups

Age groups

\begin{tabular}{lcccc}
\cline { 2 - 4 } \multicolumn{1}{c}{ Dislike } & $\begin{array}{c}\text { Teenager } \\
\mathbf{1 3 - 1 9 ( \% )}\end{array}$ & $\begin{array}{c}\text { Adult } \\
\mathbf{2 0 - 5 9}(\%)\end{array}$ & $\begin{array}{c}\text { Senior } \\
\text { Citizen60 }^{+}(\boldsymbol{\%})\end{array}$ & Total(\%) \\
\hline Noise & $29(9.7)$ & $12(4.0)$ & $1(0.3)$ & $42(14.0)$ \\
Lack of maintenance & $11(3.66)$ & $42(14.0)$ & $0(0.0)$ & $53(17.66)$ \\
Un cleanliness & $75(25)$ & $81(27)$ & $1(0.3)$ & $157(52.33)$ \\
Deforestation & $32(10.7)$ & $16(5.3)$ & $0(0.0)$ & $48(16.0)$ \\
\hline Total & $\mathbf{1 4 7}(\mathbf{6 5 . 3})$ & $\mathbf{1 5 1}(\mathbf{3 4 . 0})$ & $\mathbf{2 ( 0 . 7 )}$ & $\mathbf{3 0 0}(\mathbf{1 0 0})$ \\
\hline
\end{tabular}

Chi -Square: 10.17

P-value: 0.03 
Harris \& Sachau (2005) founded that cleanliness conveys extraordinary significance in the traveler resorts, as it can possibly affect tourist entries, proper cleanliness program by tourist department ensure intention of the visitor to revisit the tourist resorts.

\section{Visitor views about de-forestation in tourist locality.}

Forests, woodlands, and trees provide "amenity services". These attract people to visit tourist areas, improve natural landscapes and provide opportunities for recreation and tourism. Respondent were asked about ill effect due to de forestation in the tourist resorts. Chi-square test shows significant difference between ill effect due to deforestation in relation to age groups. Table 8 shows the tourist opinion about bad effect due to decrease in number of trees. Majority of respondent (74.3\%) feel ill effect over their mind followed by $25.7 \%$ fell no ill effect due to deforestation.

People felt ill effect due to deforestation is because most of the visitor came from urban areas with negligible amount of trees and abundance noise. Forest provides green, peaceful and salience environment that's why people dislike deforestation. Well managed and maintainedthe trees of the tourist areas ensure providing benefit to the local residents and visitors. Properforest management should control deforestation (SAF, 2002).Similar results was determined from national forest survey (1991) according to survey findings visitorprefer toursto that areas if the trees and ground cover were more in the tourist locality.

Table 8: Tourist views about de-forestation in relation to different age groups

Ages level

\begin{tabular}{lcccc}
\cline { 2 - 4 } Bad impact & $\begin{array}{c}\text { Teenager } \\
\mathbf{1 3 - 1 9}(\boldsymbol{\%})\end{array}$ & $\begin{array}{c}\text { Adult } \\
\mathbf{2 0 - 5 9}(\boldsymbol{\%})\end{array}$ & $\begin{array}{c}\text { Senior } \\
\text { Citizen60 }^{+}(\boldsymbol{\%})\end{array}$ & Total(\%) \\
\hline Yes & $135(45.0)$ & $86(0.7)$ & $2(0.7)$ & $223(74.3)$ \\
No & $12(4.0)$ & $65(21.3)$ & $0(0.0)$ & $77(25.7)$ \\
\hline Total & $\mathbf{1 4 7}(\mathbf{6 5 . 3})$ & $\mathbf{1 5 1}(\mathbf{3 4 . 0})$ & $\mathbf{2 ( 0 . 7 )}$ & $\mathbf{3 0 0 ( 1 0 0 )}$ \\
\hline
\end{tabular}

Chi-square: 9.074

P-value: 0.01

\section{Missing facilities in tourist locality}

Major problems facing by the tourism industry in swat valley is the provision and maintenance of those facilities mentioned as cleanliness program, foods and cold drink shops, children playing areas and transportation etc. Respondent were asked about which facility were most felt in the visitor locality. Chi-Square test shows significant different between missing facilities in relation to different age groups $31 \%$ respondent wanted children playing area in the tourist areas followed by $20.3 \%$ needed dustbin in the tourist locality, similarly $5.0 \%$ respondents required food and cold drinks shops. The reason behind most of the respondent wanted dustbin in the tourist locality is because un-cleanliness of the tourist locality is due lack of cleanliness facilities and dustbin, which makes the natural green environment unattractive. Tourism include recreational activities undertaken during travel from home or work for the leisure and enjoyment, and the facilities that cater to the needs of the tourist (Mathieson \& Wall, 1982). Similar results was confirmed by Gartner (1996) results showed that the development of facilities needed to support the tourism industry are both immediate and gradual. Facilities to be developed associated with tourism include 
Akbar J., Shah S.T, Khan M.N, Naeem A.: Role of facilities available and un-available in attracting of tourist in swat valley Pakistan

accommodations, roads, retail stores and restaurants, tourist attractions, children playing area and waste disposal facilities.

Table 10: Missing facilities in tourist resorts in relation to age groups

\begin{tabular}{lcccc}
\hline \multirow{2}{*}{ Facilities } & \multicolumn{4}{c}{ Age categories } \\
\cline { 2 - 5 } & Teenager & Adult & Senior \\
& $13-19(\%)$ & $20-59(\%)$ & Citizen60 $(\%)$ & Total(\%) \\
\hline Access to greenery & $23(7.7)$ & $22(7.3)$ & $2(0.7)$ & $47(15.7)$ \\
Children playing area & $8(2.66)$ & $36(12.0)$ & $0(0.0)$ & $44(14.66)$ \\
Dustbin & $48(16.0)$ & $62(20.66)$ & $0(0.0)$ & $110(36.66)$ \\
Security & $20(6.7)$ & $6(2.0)$ & $0(0.0)$ & $26(8.7)$ \\
Food and cold drink shops & $8(2.7)$ & $7(2.3)$ & $0(0.0)$ & $15(5.0)$ \\
Medicine & $17(5.7)$ & $7(2.3)$ & $0(0.0)$ & $24(8.0)$ \\
First Aid & $10(3.3)$ & $8(2.7)$ & $0(0.0)$ & $18(6.0)$ \\
Prayer places & $13(4.3)$ & $3(1.0)$ & $0(0.0)$ & $16(5.3)$ \\
\hline Total & $\mathbf{1 4 7 ( 6 5 . 3 )}$ & $\mathbf{1 5 1}(\mathbf{3 4 . 0})$ & $\mathbf{2 ( 0 . 7 )}$ & $\mathbf{3 0 0}(\mathbf{1 0 0})$ \\
\hline
\end{tabular}

Chi-Square: 25.67

P-value: 0.02

Awareness of tourist regarding natural green environment

Awareness of tourist regarding natural green environment mean to aware people about the importance of tourist area in tourism to the local economy. Respondent were asked to specify the importance of awareness of people regarding protection, conservation of the natural environment. Chi-square test shows significant difference between people awareness in relation to education. From table 13 most of the tourist $75.3 \%$ agreed with awareness of people to conserve and protect natural environment, respectively $16.3 \%$ not agree with awareness of people.

The reason behind the majority of people with opinion to aware people because most of the tourist do not care of natural environment by educating them we can control and conserve natural environment to improve the attraction of the locality and enhanced frequency of tourist visit to the locality. Similar results were confirmed byHarvey et al. (1995) according to them through various learning program we can instruct nearby and also visitor of the region to secure the characteristic green environment to upgraded traveler area and keep up natural green environment. 
Table 11: Awareness of Tourist Regarding Natural Green Environment

\begin{tabular}{lccccc}
\hline \multirow{2}{*}{ Awareness } & \multicolumn{5}{c}{ Education } \\
\cline { 2 - 6 } & $\begin{array}{c}\text { Secondary } \\
(\boldsymbol{\%})\end{array}$ & $\begin{array}{c}\text { Intermediate } \\
(\mathbf{\%})\end{array}$ & $\begin{array}{c}\text { Under Graduate } \\
(\boldsymbol{\%})\end{array}$ & $\begin{array}{c}\text { Graduate } \\
(\boldsymbol{\%})\end{array}$ & Total(\%) \\
\hline $\begin{array}{l}\text { Strongly } \\
\text { Agree }\end{array}$ & $6(2.0)$ & $11(3.7)$ & $21(7.0)$ & $47(15.7)$ & $85(28.3)$ \\
Agree & $22(7.3)$ & $35(11.7)$ & $41(13.7)$ & $43(14.3)$ & $141(47.0)$ \\
Undecided & $4(1.3)$ & $10(3.3)$ & $6(2.0)$ & $5(1.7)$ & $25(8.3)$ \\
Disagree & $7(2.3)$ & $6(2.0)$ & $8(2.7)$ & $9(3.0)$ & $30(10.0)$ \\
$\begin{array}{l}\text { Strongly } \\
\text { disagree }\end{array}$ & $4(1.3)$ & $6(2.0)$ & $1(0.3)$ & $8(2.7)$ & $19(6.3)$ \\
\hline Total & $\mathbf{4 3 ( 1 4 . 3 )}$ & $\mathbf{6 8}(\mathbf{2 2 . 7})$ & $\mathbf{7 7}(\mathbf{2 5 . 7})$ & $\mathbf{1 1 2}(\mathbf{3 7 . 3})$ & $\mathbf{3 0 0}(\mathbf{1 0 0})$ \\
\hline
\end{tabular}

Chi-Square: 29.00

P-value: 0.004

\section{Visitor suggestion regarding improvement of the area}

Visitor suggestion gives new ideas for future improvement in tourist locality. Tourists were asked about new ideas and suggestions regarding tourist area.Chi-Square test shows significant association visitor suggestions in relation to education groups. Most of the respondent $(53 \%)$ suggested importance of maintenance in the tourist area to improve natural greenery followed by $(26 \%)$ respondent suggested plant nurseries will improve natural greenery

The reason behind majority of the respondents agree with the enhancement of natural greenery through Maintenance is because if maintenance of the tourist resort continues which ensure more improvement in tourist resort as well as natural greenery.

\section{Conclusions and recomendations}

The following conclusions are drawn from the survey.

- Major facilities like cleanliness program are absent which helps to improve cleanliness of the locality.

- Cold drinks and stuff food should be provided to ease up tourist needs.

- Tourist department and horticulturist should develop and maintain natural greenery through proper cleanliness program, trees plantations and to avoid deforestation.

- Also to aware local peoples and visitors of the locality how to conserve and protect natural greenery in order to maintain the beauty of the tourist resorts.

- The data further indicates that un-cleanliness (throwing surplus food and other material) is the main problem with the tourist area and this is main cause of reduction of the tourists to that locality. Other reason might be the deforestation in the tourist locality. 
- Majority of the respondents were not satisfied with the maintenance and with the availability of the facilities. Dustbin, children playing area, access to natural greenery etc are some of the missed features pointed out by the tourists.

- Most of the visitor argues to aware tourist as well as local people to conserve and protect the green environment by adopting cleanliness habits.

Table 14: Visitor suggestion regarding improvement of the area in relation to education groups.

Education groups

\begin{tabular}{lccccc}
\cline { 2 - 5 } $\begin{array}{c}\text { Visitor } \\
\text { suggestions }\end{array}$ & $\begin{array}{c}\text { Secondary } \\
(\boldsymbol{\%})\end{array}$ & $\begin{array}{c}\text { Intermediate } \\
(\boldsymbol{\%})\end{array}$ & $\begin{array}{c}\text { Under } \\
\text { Graduate } \\
(\mathbf{\%})\end{array}$ & $\begin{array}{c}\text { Graduate } \\
(\boldsymbol{\%})\end{array}$ & Total(\%) \\
\hline Plant nurseries & $3(1.0)$ & $12(4.0)$ & $23(7.7)$ & $42(14.0)$ & $80(26.7)$ \\
Maintenance & $26(8.7)$ & $37(12.3)$ & $43(14.3)$ & $54(18.0)$ & $160(53.3)$ \\
Policies & $6(2.0)$ & $6(2.0)$ & $5(1.7)$ & $4(1.3)$ & $28(9.3)$ \\
Awareness & $8(2.66)$ & $13(4.3)$ & $6(2)$ & $12(4)$ & $39(13)$ \\
\hline Total & $\mathbf{4 3 ( 1 4 . 3 )}$ & $\mathbf{6 8}(\mathbf{2 2 . 7})$ & $\mathbf{7 7}(\mathbf{2 5 . 7})$ & $\mathbf{1 1 2}(\mathbf{3 7 . 3})$ & $\mathbf{3 0 0}(\mathbf{1 0 0})$ \\
\hline
\end{tabular}

Chi-Square: 27.22

P-value: 0.07

\section{REFERENCES}

Anonymus, (2002, March). Analysis tourism management in Pakistan chapter 5 Establishment \& Administration Department, NWFP. Retrieved on March 6, 2002 from ULR: prr.hec.gov.pk/chapters/7s-5.pdf.

Aranzabal, I., Schmitz, M. and F. Pineda, (2009). Integrating Landscape Analysis and Planning: A Multi-Scale Approach for Oriented Management of Tourist Recreation. Environmental Management, 44(5), 938-951.

Arjun, R., (2013, January). Components of tourism. Retrieved on January 24, 2013 from http://www.slideshare.net/ArjunRamesh1/components-of-tourism

Arnberger, A. \& R. Eder, (2011). In his study Coping as a Moderator of The Relation between Recreation Hassles and Hiker Satisfaction, including surveys were conducted on trails in Yangmingshan National Park in Taiwan. Contemporary Manag Res - pp. 273-286, Vol. 10, No. 4.

Ayeni, D.A., (2012). Landscape element As Important Components of a sustainable built environment. Developing Country Studies, 2(8), 33-43.

Bell, C. \& J.G.P.G. Lyall, (2002). The Accelerated Sublime: Landscape, Tourism and 
Identity. Westport, USA: Greenwood Publishing Group.

Bigne, J.E. \& L. Andreu, (2004). Effective satisfaction and servicios of leisure and tourism. J. Eco and Business, 21, 89-120.

Browne, T. (1992). Landscape survey over the perception of tourist in polland, Jouranal of landscape, 04, 08.

Buckley, R., (2003). The practice and politics of tourism and land management, In nature-based tourism, Environment and land management 2.7, Cambridge (CABI Publishing).

Carl, O.C., (1925). The Morphology of Landscape". University of California Publications in Geography, 02, 37.

Chi, T. \& Qu, H., (2008, 15th February). Tourism and Landscape: Between Conflict and Common Interests. Paper presented at the International Conference Ljubljana Slovenia.15th Feb. 2008, Ljubljana Slovenia.

Oliver, R. L., (1980). A cognitive model of the antecedents of satisfaction decisions. Journal of Marketing Research, 17, 460-469.

Ong, A. (2003). Tourism Industry In Penang: Reflections and Improved Dimensions. Economic Briefing To the Penang State Government, 5 (1), pp. 2-6.

Pakistan Tourism and Travel guide, (2006, March). Pakistan Tourism and Travel guide. Retrieved March 20, 2006 from http://www28.brinkster.com/pakistan4ever/default.asp.

Pretty, J., Peacock, J., Hine, R., Sellens, M., South, N. and M. Griffin, (2007). Green exercise in the UK countryside: Effects on health and psychological well-being, and implications forpolicy and planning. Journal of Environmental Planning and Management 50(2): 211231.

Scrinzi, G.J. \& V. Agatea, (1995). The Italians and the forest; coordinates and quantitative user tourist in Italy (Italians and the wood). The forest recreantion demand in Italy Communications Research ISAFA 95/1

Shanklin, W. \& J., Michael, (1991). Solid Waste Management in Selected Hotel Chains and Individual Properties. Hospitality Research Journal: The Professional Journal of the Council on Hotel, Restaurant, and Institutional Education, 15 (1), 59-74.

Silva, M.A., (1996). The meaning of the tree to the city and the people of Geneva. Chair of Forest Policy and Forest Economics, Swiss Federal Institute of Technology, Zurich, pp 453463

Spencer, D., (1997). Counter urbanization and rural depopulation revisited: Landowners, planners and rural development, of Rural Studies in parts of rural Britain, Jr of Rural Std, 13(1): 75-92. 